\title{
The influence of dividend policy on the volatility of shares in the Romanian equity capital market
}

\author{
Ciprian Cristea ${ }^{1, *}$, Maria Cristea $^{1}$ \\ ${ }^{1}$ Technical University of Cluj-Napoca, Faculty of Electrical Engineering, Romania
}

\begin{abstract}
Dividend policy is one of the most debated topics in corporate finance and, at the same time, it represents an important issue from the perspective of both the managers of the firm and the investors. To the best of our knowledge, the literature regarding establishing the relationship between dividend policy and share price volatility of non-financial companies listed on Romanian stock market remains inexistent. This study attempts to identify how the share price volatility of non-financial companies listed on the Bucharest Stock Exchange for a period of sixteen years from 2002 and 2017 is influenced by corporate dividend policy. Results from a cross sectional multiple regression analysis revealed a negative effect of the two components of the dividend policy on the share price volatility. The results support the idea that the lower the dividend yield, the higher the risk to be faced by the shareholder. Growth in assets and share price were negatively related. Positive relationship between firm size and debt ratio to price volatility were identified. However, there was no significant relationship found between earning volatility and price volatility in the Romanian stock market.
\end{abstract}

\section{Introduction}

Dividend policy is one of the most debated and challenging topics in modern financial economics both in emerging and developed economies [1]. Dividend policy is a set of guidelines used by a company to establish how much of its earnings should be distributed to the shareholders as dividends and how much to be reinvested in new opportunities. Corporate finance research has investigated why corporations pay dividends, referred to as the "Dividend Puzzle" by [2]. Notwithstanding the comprehensive research on dividend policy over the past decades, no universally accepted explanation is acquired [3]. Hence, more efforts should be implemented to uncover the puzzle.

Dividend policy represents an important decision, usually made by top managers, which demands the final agreement of the board of directors. Managers have to take into account which dividend policy will lead to maximization of shareholder's wealth, how much of company's earnings are needed for investment, and last, but not least they have to analyze the impact of their decision on stock's price [4].

In general, the theoretical framework for explaining the relationship between dividend policy and stock price volatility over the last decades has been dominated by dividend irrelevance theory, bird-in-the-hand theory, signaling theory, agency theory and clientele effects of dividend theories.

Dividend policy proposed by [5] state that dividend payment have no effect on company value and no dividend policy is superior to another under perfect capital market assumptions. The shareholders wealth is not influenced by dividend policy. The company's earnings, coming from firm's investment policy, determine the value of the company. If a company distributes its profits as dividends, then the stock price will be decreased by the amount of a dividend per share on the ex-dividend date. In a perfect market, without taxes and brokerage costs, dividend policy does not alter the shareholder's return.

Bird-in-the-hand theory asserts that in a world of uncertainty and information asymmetry, investors prefer dividends over the capital gains, even if the promised dividend is larger, due to uncertainty of future cash flows [6]. This perspective is consistent with the view that "a bird in hand is worth more than two in the bush" and supports the results of [7-8].

The dividend paid to shareholders encompasses information about the prediction of the company [9]. Even though [5] assumed that investors and management have perfect knowledge about a company, it is unrealistic to believe that they have the same amount of data and, because of this, firms pay dividend to send a signal to their investors that their company is financially stable and remain profitable [10]. Increasing the dividend can be seen as a good sign, notifying the owners that managers are working in their best interest, and thus, can affect the share price positively [6].

Agency theory establishes the role of dividends in controlling agency relationships between managers and shareholders and, by paying dividend, it compels the company to raise additional funds from the capital market, thus decreasing the scope for agency conflicts and exposing the firm to the discipline of the market [11]. Agency cost represents the cost of the conflict of interest between management and shareholders and management,

\footnotetext{
Corresponding author: ciprian.cristea@emd.utcluj.ro
} 
namely when management team, instead of acting on behalf of the owners of the company (shareholders), they act on their behalf [12].

The clientele effect is a theory that explains that due to the fact that investors are taxed in different individual brackets, the difference between dividend taxes and capital gains taxes would lead to clientele preference [13]. Thus, investors who pay low taxes on dividends would be concerned in purchasing high dividend yielding stocks, while investors who pay high taxes on dividends would prefer to buy low dividend yielding stocks [13].

The dividend policy literature is vast and contains numerous theories and hypotheses. Notwithstanding voluminous theorizing and empirical research, no consensus exists among researchers on the impact of dividend policy on share price.

Furthermore, many researchers investigated the association between share price volatility and dividend policy. The common stock's volatility is a measure used to establish risk, indicating the rate of change in the stock's price over a determined period [14]. The smaller the volatility, the smaller possibility of gain or loss in short-term is. Volatility deals with the variance of a stock's price. The price of less volatile stock would not differ notably over time and it is not difficult to predict the future price of this security [4]. Normally, investors select less risky investments [4].

There are several studies examined the relationship between dividend policy and share price volatility. In Malaysia [4] studied the effect of the dividend policy on the stock price volatility from 2005 and 2010. The price volatility is associated negatively with both proxies of the dividend policy. In the UK stock market [14] found a significant and negative relationship between the payout ratio and dividend yield with the stock price volatility. In the US equity capital market dividend policy and stock price volatility is analyzed by ordinary least square regression [10] and, the stock with high dividend is less risky. In Brazil, [15] examined the relationship between the dividend policy and the risk of stocks, in the period 2000-2012, and it was found that the dividend policy is significant in determining the volatility, establishing that the lower the dividend yield, the higher the risk to be faced by the shareholder. [16], on the other hand, found that payout is not related to stock price volatility. In Karachi stock exchange, [17] found the relationship between stock price volatility and dividend yield to be positive and significant.

In this paper, we investigate the relationship between dividend policy and share price volatility of non-financial companies listed on the Bucharest Stock Exchange Market for a period of sixteen years from 2002 to 2017. In this study, multiple regression analysis is applied to explore the association between share price changes and both dividend yield and dividend payout ratio of the Romanian firms mentioned above. This research has important implications for both theory and practice. No study, to the best of our knowledge, has examined the relationship between dividend policy and share price volatility on the Romanian market. Our findings have implications for corporate finance literature, academics, investors, and policymakers in emerging markets.
The rest of the paper is organized as follows: in the next paragraph the methodology is described, moreover, the empirical results are presented in the third section and, finally, the last section summarizes the conclusions.

\section{Methodology}

The goal of this paper is to study the relationship between dividend policy and share price volatility using multiple least square regressions. Primarily, we conducted a basic test of the relationship between price volatility and the two most important measures of dividend policy: dividend yield and dividend payout ratio.

The model used in this paper is based on the previous literatures commenced by [16]. Following $[4,10,14,16]$, several control variables were included to account for certain factors that affect both stock price volatility and dividend policy, namely, firm size, growth in assets, debt ratio and earnings volatility.

The financial data were collected from the annual reports and financial statements of 175 Romanian nonfinancial companies listed on the Bucharest Stock Exchange Market over the period 2002-2017. The firms included in the sample had at least one cash dividend during period 2002 to 2017 . The data regarding share prices were obtained from Romanian equity capital market and transformed into an appropriate form so as to be used for the study.

The dependent variable is share price volatility. Firstly, to obtain a crude test of the relationship between price volatility and dividend policy, dependent variable is regressed against the most important independent variables, namely, dividend yield and payout ratio utilizing multiple least square regression based on following equation:

$$
P V_{i}=\alpha+\beta_{1} \cdot D Y_{i}+\beta_{2} \cdot P R_{i}+e_{i}
$$

where:

$\alpha$ - constant;

$\beta$ - regression coefficient;

$P V_{i}$ - share price volatility for company $i$;

$D Y_{i}$ - dividend yield for company $i$;

$P R_{i}$ - payout ratio for company $i$;

$\varepsilon$ - error term.

The price volatility $(P V)$ is utilized to capture the movement in share price changes and to measure the risk of the stock. For each year, it is computed by taking the difference between highest and lowest share prices and dividing by the average of highest and lowest prices and then by taking the square of it. Following [16], the formula for computing the annually share price volatility is as follows:

$$
P V_{i}=\sqrt{\frac{H P_{i}-L P_{i}}{\left(\frac{H P_{i}+L P_{i}}{2}\right)^{2}}}
$$

where:

$H P_{i}$ - highest share price for company $i$;

$H P_{i}-$ lowest share price for company $i$. 
Dividend yield $(D Y)$ is calculated by taking all cash dividends paid to common stock holders in a year and then dividing them by share price. Payout ratio $(P R)$ is computed as the ratio of dividend per share to earning per share.

Dividend yield and dividend payout ratio are closely related to each other. Thus, a multicollinearity problem is likely to arise. To limit this problem, the control variables specified earlier were included. Thereby, the estimation model is modified as follows:

$$
\begin{gathered}
P V_{i}=\alpha+\beta_{1} \cdot D Y_{i}+\beta_{2} \cdot P R_{i}+\beta_{3} \cdot S Z_{i}+\beta_{4} \cdot D R_{i}+ \\
\beta_{5} \cdot E V_{i}+\beta_{6} \cdot G R O W_{i}+\varepsilon_{i}
\end{gathered}
$$

where:

$S Z_{i}$ - firm size for company $i$;

$G R O W_{i}-$ growth in assets for company $i$;

$D R_{i}$ - debt ratio for company $i$;

$E V_{i}$ - earnings volatility for company $i$.

Size $(S Z)$ is one of the control variable measured by using the natural logarithm of total assets [18]. Growth in assets (GROWTH) is determined as the ratio of the change in total assets at the end of the year to the level of total assets at the beginning of the year [14]. Debt ratio $(D R)$ is the ratio of total debt to total assets. Earnings volatility $(E V)$ is the standard deviation for the ratio of operating profit to total assets.

\section{Results}

Table 1 shows a broad description of the summary statistics of the variables used in the study. It shows the statistical means and standard deviation. Following [19], if it is assumed that share prices follow a normal distribution and the effect of company's going exdividend is not took into consideration, the standard deviation of stock market returns correspond to the determined volatility of this study [14]. It can be computed using [20] formula. Thus, the mean of price volatility 0.8093 , is multiplied by the constant 0.6008 which return a result of $48.62 \%$. This is higher that of UK (17.66\%) companies [14] and Australian (29.42\%) companies [19], but lower that of Pakistani (48.85\%) companies [21].

Table 1. Descriptive statistics of variables.

\begin{tabular}{|c|c|c|}
\hline & Mean & Std. Dev. \\
\hline PV & 0.809382 & 0.793112 \\
\hline DY & 0.044468 & 0.085295 \\
\hline SZ & 0.399657 & 0.812162 \\
\hline GROW & 0.165239 & 0.704577 \\
\hline DR & 0.276865 & 0.239220 \\
\hline EV & 0.019598 & 0.029877 \\
\hline
\end{tabular}

Table 2 shows the Pearson correlation coefficients for the variables used in this paper. According to our expectation and to the results obtained in other studies [4, $14,15]$ we found a statistically negative correlation coefficient between price volatility and dividend yield, but it differs from that of [19] which was positive. Likewise, the correlation between price volatility and dividend payout is statistically negative as expected and is similar to $[14,15]$.

Table 2. Correlation matrix.

\begin{tabular}{|c|c|c|c|c|c|c|c|}
\hline & PV & DY & PR & SZ & GROW & DR & EV \\
\hline PV & 1 & & & & & & \\
\hline DY & $-0.176^{* *}$ & 1 & & & & & \\
\hline PR & $-0.128^{* *}$ & $0.422^{* *}$ & 1 & & & & \\
\hline SZ & $0.057^{*}$ & -0.011 & $0.07 * *$ & 1 & & & \\
\hline GROW & $-0.071^{* *}$ & 0.009 & -0.047 & -0.014 & 1 & & \\
\hline DR & $0.082^{* *}$ & $-0.143^{* * *}$ & -0.112 & 0.049 & 0.02 & 1 & \\
\hline EV & 0.01 & $0.054^{*}$ & -0.07 & $-0.23^{* *}$ & -0.021 & $0.178^{* *}$ & 1 \\
\hline
\end{tabular}

Notes: $\left({ }^{*}\right)$ implies significance at $5 \%,(* *)$ implies significance at $1 \%$

Table 3 shows the results of regression based on equation (1). The results of this regression show that price volatility and the two components of dividend policy have significant negative association.

Table 3. Results of regression based on equation (1).

\begin{tabular}{|c|c|c|c|}
\hline Variable & Coefficient & t-Statistic & P-values \\
\hline C & 0.896723 & 36.45901 & 0 \\
\hline DY & -1.388043 & -5.091325 & 0 \\
\hline PR & -0.064099 & -2.238692 & 0.0253 \\
\hline
\end{tabular}

Consistent with previous findings, the study reports a significant negative relationship between price volatility and dividend yield [4, 14].

In the next phase, the four control variables were added to notice if there would be any change in the coefficients of dividend policy components. Table 4 presents the results of regression based on equation (3). It can be noticed that the significant negative association between share price volatility and dividend yield remains. This is in line with our expectation and to the results obtained in other studies $[4,10,14,15]$. Thus, the lower the dividend yield, the higher the risk to be faced by the shareholder. Also, the negative association between share price volatility and dividend payout remains and it is significant. The result is consistent with previous findings $[4,14,15,21]$, except that those findings are not statistically significant. 
Table 4. Results of regression based on equation (3).

\begin{tabular}{|c|c|c|c|}
\hline Variable & Coefficient & t-Statistic & P-values \\
\hline C & 0.383919 & 1.791055 & 0.0735 \\
\hline DY & -1.297521 & -4.719696 & 0 \\
\hline PR & -0.069068 & -2.399844 & 0.0165 \\
\hline SZ & 0.026788 & 2.230776 & 0.0259 \\
\hline DR & 0.165321 & 1.820868 & 0.0688 \\
\hline GROW & -0.082076 & -2.749157 & 0.0061 \\
\hline EV & 0.450626 & 0.607971 & 0.5433 \\
\hline
\end{tabular}

As table 4 shows, there is a significant positive association between price volatility and firm size. The result is not in line to the results obtained in other studies $[10,14,15]$. The study reveals a negative relationship between price volatility and growth in assets. The result is similar with prior findings [4].

A positive association between price volatility and earnings volatility is found, implying that firms which have more volatility in their earnings have more volatility in their stock price, but the association is not significant.

\section{Conclusions}

This paper examines the relationship between dividend policy (dividend yield and dividend payout) and the volatility of stock price by applying multiple regression. For this purpose, a sample of 175 nonfinancial companies listed on the Bucharest Stock Exchange market between 2002 and 2017 were selected. Also, the study examined the relationship between stock price volatility and the control variables, namely, firm size, growth in assets, debt ratio and earnings volatility.

The empirical findings report that there is a significant negative relationship both between the payout ratio of a company and the volatility of its share price, and between dividend yield and the volatility of stock price. The findings suggest that the less the payout ratio the higher volatile a share price would be. The study noticed that share price of firms with high dividend yield can be associated with nearby cash, which decrease the uncertainty regarding the cash flows of the company leading to less price volatility. Among the control variables, debt ratio indicates a positive relationship with price volatility implying that the less leveraged a company is, the less volatile would be the share price.

The results of this study reveal that the dividend policy has an impact on the price volatility, and that the managers of the firms have the capacity to affect their company's stock price by adjusting dividend policy that is convenient for their target investors. The results of this paper are useful for academics, analysts and investors in emerging markets.

\section{References}

1. G. M. Frankfurter, B. G. Wood Jr., Int. Rev. Financ. Anal., 11, 111-138 (2002)

2. F. Black, JPM, 2, 5-8 (1976)

3. H. K. Baker, J. C. Singleton, E. T. Veit, Survey Research in Corporate Finance: Bridging the Gap between Theory and Practice (Oxford University Press, Oxford, 2011)

4. M. Hashemijoo, A. Mahdavi Ardekani, N. Younesi, JBSQ, 4(1), 111-129 (2012)

5. M. Miller and F. Modigliani, J BUS, 34, 411-433, (1961)

6. H. N. Al-Malkawi, JAAR, 23, 44-70 (2007)

7. M. J. Gordon, J. Fin., 18(2), 264-272 (1963)

8. J. Lintner, Rev. Econ. Stat., 44(3), 249-263 (1962)

9. R. R. Petit, J. Fin., 27, 993-1007 (1972)

10. K. A. Profilet and F. W. Bacon, BS, 20 (1), 219-231 (2013)

11. R. Manos, V. Murinde, C. J. Green, IREF, 21, 42-56 (2012)

12. S. A. Ross, R. W. Westerfield, J. Jaffe, B. D. Jordan, Modern Financial Management ( $8^{\text {th }}$ ed., McGrawHill International, 2008)

13. J. L. Procianoy and R. S. Verdi, RAE, 8(1) (2009)

14. K. Hussainey, C. O. Mgbame, A. M. ChijokeMgbame, J. R. FINANC., 12(1), 57-68 (2011)

15. C. Silva and M. A. V. Machado, RC\&C, 7(3), 8-20 (2015)

16. J. Baskin, JPM, 15(3), 19-25 (1989)

17. M. Asghar, S. Z. A. Shah, K. Hamid, M. T. Suleman, FJSB, 4(1), 45-52 (2011)

18. I. Jabbouri, RES INT BUS FINANC, 37, 283-298 (2016)

19. D. E. Allen and V. S. Rachim, J. Appl Econ, 6, 175188 (1996)

20. M. Parkinson, J Bus., 53, 61-65 (1980)

21. Y. Habib, Z. I. Kiani, M A. Khan, GJMBR, 12(5) (2012) 